\title{
Aneta Dawidowicz, Myśl polityczna Stronnictwa Narodowego 1928- 1939. Wspólnota ideału czy alternacja koncepcji
}

\author{
Wydawnictwo Uniwersytetu Marii Curie-Skłodowskiej, Lublin 2017, 409 ss.
}

DOI: $10.19195 / 1643-0328.26 .15$

Recenzowana praca dotyczy myśli politycznej Stronnictwa Narodowego w latach 1928-1939. Oparta jest na wnikliwych i bardzo sumiennie przeprowadzonych badaniach: źródłowych, bibliograficznych, prasowych i epistolograficznych. Cezura czasowa (skądinąd dość wąska) wskazuje na rozległe ujęcie problematyki. Wykaz zróżnicowanych materiałów i źródeł archiwalnych, bibliograficznych czy prasy wykorzystanych w rozprawie i tak sformułowany tytuł pracy obejmuje nie tylko zagadnienia polityczne, lecz także problematykę gospodarczą, filozoficzną, mniejszości narodowe, wizje ustroju państwa, usytuowanie Polski w środowisku międzynarodowym.

Autorka poświęciła we wstępie nieco miejsca kwestiom źródeł i ich praktycznego wykorzystania, co pozwoliło ukształtować określoną koncepcję badań i sformułować hipotezę badawczą. Ma niewątpliwie rację, suponując, że poglądy Stronnictwa Narodowego zasługują na uwagę $\mathrm{z}$ powodu znaczenia tej partii w życiu politycznym II RP oraz interesującej symbiozy w jej programie różnorodnych elementów koncepcyjnych, wywodzących się z niejednorodnych prądów ideowych. Zasadne zatem wydaje się założenie, że bogaty dorobek ideowy, koncepcyjny i programowy SN ma wymiar i znaczenie wciąż aktualne, zważywszy, że efektem podjętej przez autorkę refleksji dotyczącej „rzeczywistości politycznej” jest także „próba prognozowania czy formułowania własnej wizji ładu politycznego" (s. 14).

Wadą tej ambitnej syntezy jest niezałożenie hipotezy podstawowej o znaczeniu ogólnym w aspekcie praktycznym lub kilku cząstkowych hipotez oraz pytań badawczych, które umożliwiłyby prześledzenie i weryfikację założeń programowych tej formacji politycznej nie tylko w ujęciu opisowym. Pewnym usprawiedliwieniem przyjętych przez Anetę Dawidowicz założeń hipotetycznych było uporanie się (nie tylko w ujęciu normatywnym) z desygnatami takich pojęć, jak: nacjonalizm, myśl nacjonalistyczna i różne ich konotacje, wizje ustroju państwa, wizje narodu, modelu gospodarczego, bezpieczeństwa i położenia międzynarodowego RP. W tym przypadku autorka spełniła trudny warunek eliminowalności definiowanego terminu niemal z każdego możliwego kontekstu, jakkolwiek niepozbawionego pewnych wad.

Znaczenia tych pojęć nieustannie się zmieniają, zwłaszcza gdy w interpretacji procesów społeczno-politycznych czy przemian historycznych pomniejszamy lub wykluczamy znaczenie logiki i metodologii i odwołujemy się do relatywizmu, twierdząc subiektywnie, że prawda jest nierozpoznawalna. Badacze takich zapatrywań zapominają, że argument ten jest skażony poważnym błędem logicznym - niewynikania (non sequitur) i jeśli ścierają się różne stanowiska, „nie wynika z tego subiektywność i względność prawdy naukowej” określanej jako logika nowo- 
czesności lub ponowoczesności ${ }^{1}$. Pisanie prac naukowych w konwencji „modnych bzdur” ma niewiele wspólnego z naukowym podejściem versus hermeneutycznym. Autorka tego uniknęła, co wskazuje na umiejętność dostrzeżenia tego, co w myśli politycznej jest ważne.

Oczywiście można oprzeć koncepcje badań na konkretnym modelu interpretacji i doszukiwać się szerszej perspektywy, ale w kontekście zamkniętej perspektywy czasowej lat 1928-1939 jest to raczej nieuzasadnione, zwłaszcza w odniesieniu do problemu etnonacjonalizmu czy populizmu nacjonalistycznego. Dobrze, że Dawidowicz nie podjęła tego zagadnienia w ujęciu szerszym, uwzględniając współczesną perspektywę badawczą. Inne były realia historyczne i polityczne w II Rzeczypospolitej, a inne są obecnie. Stawiane więc pytanie w podtytule książki: „Wspólnota ideału czy alternacja koncepcji” nie do końca jest zasadne, zważywszy, że cezura czasowa jest wąska i trudno rozpatrywać i analizować ewolucję polskiego nacjonalizmu w świetle współczesnych doświadczeń i nadawać im dawne lub aktualne znaczenie.

Zapewne niektórzy krytycy i recenzenci będą próbowali ocenić książkę w takim właśnie kontekście, ale przyjęcie sygnalizowanych założeń w odniesieniu do myśli programowej SN niekoniecznie jest słuszne, a na pewno budzi wiele wątpliwości teoriopoznawczych i metodologicznych. Autorka wyraźnie określiła zakres swoich rozważań - nie tylko przedmiotowy, lecz także na poziomie usytuowania w obrębie kontinuum konkret-abstrakcja — i wykorzystała bogate i pieczołowicie zebrane źródła, które poddała gruntownej interpretacji i wprowadziła nową porcję wiedzy.

Oczywiście po lekturze książki dostrzegam pewne luki źródłowe. Przykładowo słabo wykorzystano źródła do dziejów Obozu Wielkiej Polski. Brakuje w wykazie prasy kilku regionalnych tytułów, na przykład: „Kurier Lwowski”, „Kurier Wileński”, „Słowo Polskie” we Lwowie, „Goniec Warszawski”. Można się także zastanawiać, dlaczego podczas kwerendy źródłowej w Bibliotece Narodowej pominięto spuścizny na przykład Romana Dmowskiego, Jerzego Drobnika, Kazimierza Fudałowskiego, Stanisława Grabskiego, Klaudiusza Hrabyka, Wincentego Brunona Borotyńskiego, Stanisława Kozickiego, Andrzeja Wierzbickiego. Również w Bibliotece Zakładu Narodowego im Ossolińskich we Wrocławiu znajdują się wspomnienia Stanisława Grabińskiego, Klaudiusza Hrabyka czy Juliusza Zdanowskiego. Dlaczego do nich nie sięgnięto i czy mogłyby istotnie uzupełnić źródła, oto zasadnicze pytania, na które próżno szukać odpowiedzi w pracy.

Dyskusyjna może być kwestia pojęcia myśl polityczna-historia idei, zważywszy, zdaniem niektórych badaczy, na niejednoznaczność tych pojęć na poziomie metateoretycznym. Jest to istotny problem, który pośrednio autorka rozstrzygnęła. Należałoby zatem odwołać się do konstatacji Romana Wapińskiego, że myśl polityczna w czystej postaci nie istnieje. Zbyt obszerne, ale płytkie definicje wypaczają sens myśli politycznej i skłaniają część badaczy do pisania o „historii idei” „dziejach wyobrażeń, poglądów, zachowań”, a nie o myśli politycznej². Z perspektywy ostatnich kilkudziesięciu lat słuszna wydaje się zatem teza, że bez historii idei czy myśli przewodnich ruchy polityczne trudno byłoby porządkować rzeczywistości społeczno-politycznej i projektować w wymiarze programowym określone wizje polityczno-ustrojowe.

Pod względem konceptualizacyjnym praca została właściwie zakomponowana, choć nie można wykluczyć innego jeszcze układu tematycznego i kolejności poszczególnych rozdziałów. Brakuje na przykład osobnego rozdziału poświęconego kwestii stosunku SN wobec III Rzeszy i nazizmu. Nie bardzo wiadomo, dlaczego autorka nie omówiła innych jeszcze zagadnień, na

1 J.R. Sielezin, Poprawność polityczna jako ograniczanie prawa do wolności słowa i swobody badań naukowych, [w:] Współczesna oblicze demokracji, red. D. Gizicka, Toruń 2010, s. 169.

2 Zob. na przykład J.J. Chevalier, Histoire de la peénse politique, Paris 1993 s. 9; I. Philips, Histoire de la pensée politique en France de 1789 à nos jours, Paris 1998, s. 5; R. Scruton, A Dictionary of Political Thought, London 1996, s. 432. 
przykład kultury narodowej, oświaty i szkolnictwa wyższego, które powinny być uwzględnione w osobnych rozdziałach jako istotne w rozumieniu koncepcji programowych tej partii. O przyjęciu takich założeń koncepcyjnych dotyczących struktury pracy i pominięciu innych powinna napisać we wstępie.

Recenzowana praca składa się ze: wstępu, siedmiu rozdziałów, zakończenia, wykazu źródeł i opracowań oraz niezmiernie przydatnego indeksu nazwisk. Refleksje i rozważania dotyczące kwestii zasadniczych - myśli politycznej SN - zostały umiejętnie wkomponowane w tok narracji, widać dbałość o pewną koncepcję przekazu. Pracę mogą zatem studiować z pożytkiem i czytać z zainteresowaniem osoby niekoniecznie z wykształceniem humanistycznym, co świadczy o jej walorach poznawczych i syntetycznych.

Z obowiązku recenzenta mam pewne uwagi i propozycje dotyczące niektórych rozdziałów pracy. Rozdział pierwszy nie budzi zasadniczych wątpliwości i świadczy o umiejętnościach syntetyzowania informacji. Dotyczy: genezy SN, działalności statutowej w aspekcie politycznym, strukturalnym i personalnym, działalności propagandowej między innymi na łamach prasy narodowej.

W rozdziale drugim przeanalizowano założenia ideowe $\mathrm{SN}$ w aspekcie „recepcji nurtów i teorii naukowych" i dokonano pragmatycznej oceny przeszłości historycznej. Autorka przyjęła ujęcie aksjologiczne i powołała się na idee: pozytywizmu europejskiego, materializmu, empiryzmu, sensualizmu, racjonalizmu, które są widoczne w pracach Jędrzeja Giertycha, Romana Rybarskiego, Zygmunta Balickiego czy Romana Dmowskiego. Dostrzegła i wskazała na twórcze inspiracje zewnętrzne jako źródła myśli politycznej i założeń programowych SN. Można mieć jednak zastrzeżenia do poruszonej lakonicznie kwestii żydowskiej (s. 86-88). Ta część powinna być dołączona do rozdziału czwartego, poświęconego między innymi mniejszości żydowskiej (s. 183-209), gdyż w takim założeniu konstrukcyjnym burzy ona tok narracji. Rozdział jest dobrze udokumentowany i zawiera zamienne elementy analizy i refleksje, które nie naruszają wymogu zgodności treści $\mathrm{z}$ tematem rozdziału.

W rozdziale trzecim autorka dokonała analizy podstawowych dla tego nurtu ideowo-politycznego pojęć, takich jak: naród, idea narodu, wspólnota narodowa, psychika narodowa, patriotyzm, wychowanie narodowe, religia katolicka. Ukazała złożone relacje między katolicyzmem i nacjonalizmem w kontekście relacji naród-państwo. Słusznie zauważyła, że dyskusje o „optymalnym ustroju politycznym państwa” między „młodymi i starymi” miały zasadniczy wpływ na wizje przyszłości państwa i narodu. Można mieć jedno zastrzeżenie - dlaczego ten spór został pobieżnie przeanalizowany, o czym pośrednio świadczą konkluzje podsumowujące ten aspekt. Za wartościowe należy uznać wątki poświęcone konterfektowi wewnętrznemu Polaka i charakteru narodowego oraz uwzględnienie negatywnych opinii o Polakach, a także tendencje do idealizacji cech narodowych, o których krytycznie pisali publicyści narodowi. Autorka trafnie zauważyła, że w środowisku narodowym spory niepokój wzbudzały bierność i obojętność na sprawy narodowe, które postrzegano jako wadę charakteru polskiego. Akcentowany w odniesieniu do poszczególnych grup postulat wzmocnienia poczucia świadomości narodowej jest jak najbardziej zasadny, pod warunkiem że ten wątek rozważań byłby oparty na większej liczbie źródeł dotyczących tego zagadnienia.

W kolejnym rozdziale poruszono kwestie mniejszości narodowych, między innymi żydowskiej, słowiańskiej, niemieckiej, zamieszkujących terytorium II Rzeczypospolitej. Najciekawszy tematycznie wydaje się rzeczywisty czy urojony wątek zagrożenia żywiołem żydowskim, przy czym należało oprzeć się między innymi na danych statystycznych (wprawdzie niepełnych), które zapewne pokazałyby, o jaką skalę problemu spierali się publicyści SN. Może częściowo problem udałoby się rozwiązać, gdyby autorka dotarła do roczników statystycznych z lat trzydziestych 
$\mathrm{XX}$ wieku, co pozwoliłoby przeanalizować problem w sposób bardziej zobiektywizowany. Autorka słusznie zauważyła, iż poglądy czołowych publicystów narodowych ewoluowały, ale nie wyjaśnia, czy przyczyną była złożona sytuacja międzynarodowa i krajowa, czy może wynikały one z „rozgrywek i animozji natury personalnej” (s. 208).

Ten fragment pracy jest nieco wtórny tematycznie, gdyż zamiast analizy z elementami naukowej polemiki mamy do czynienia z powieleniem poglądów innych badaczy, co jest może i dopuszczalne, ale należy to czynić z umiarem, zwłaszcza gdy stosujemy jedną metodę badawczą lub cytujemy jedno źródło. W takich sytuacjach istnieją pewne dyrektywy metodologiczne, a pomijanie ich lub wybiórcze stosowanie nie przyczynia się do pogłębienia prawdy naukowej. Badacz obraca się wówczas w kręgu półprawd lub tautologii. Zresztą problem żydowski w publicystyce i programach partii narodowych jest złożony, delikatny i metodologicznie trudny do ogarnięcia. Wzrost postaw i nastrojów antyżydowskich w drugiej połowie lat trzydziestych XX wieku miał niewątpliwie związek z ogólną sytuacją międzynarodową w Europie, a także z rozwojem postaw antysemickich w Europie, a zwłaszcza z polityką Włoch i III Rzeszy ${ }^{3}$.

Lepiej prezentują się kolejne podrozdziały dotyczące mniejszości słowiańskiej (ukraińskiej i białoruskiej) oraz mniejszości niemieckiej. Należy jednak wspomnieć, że choć autorka stara się kontrolować z pozycji metateoretycznej i źródłowej postępowanie badawcze, to daje się jednak zauważyć, że brakuje kilku ważnych pozycji naukowych i publicystycznych, które pogłębiłyby omawianą problematykę $e^{4}$ Mimo tych uwag krytycznych i wskazania jako uzupełnienie kilku propozycji bibliograficznych logika układu treści podrozdziału jest przejrzysta i podporządkowana problematyce zawartej w tytule rozdziału. Można mieć jednak zastrzeżenie do pobieżnie omówionego antagonizmu polsko-ukraińskiego w kontekście konfliktu etnicznego (ale czy tylko?), a zwłaszcza działalności terrorystycznej OWU-OUN. Otwarte pozostaje zatem pytanie, czy problem ten był podejmowany na łamach prasy SN i jeśli tak, to w jaki kontekście i zakresie?

Rozdział piąty dotyczy wizji ustroju państwa, form władzy państwowej, organów wykonawczych i ustawodawczych, wymiaru sprawiedliwości, i organów kontrolnych oraz kształtu samorządu terytorialnego. Tak rozległą problematykę autorka rozpatruje w kontekście nadejścia „silnych rządów”, przy czym mocno wyartykułowała dystans wobec współczesnych systemów totalitarnych, które „traktowała jako negatywne ramy systemu własnego” zwłaszcza zawierające krytykę parlamentaryzmu, co nie oznaczało porzucenia demokracji parlamentarnej.

Rozdział ten jest dobrze udokumentowany, ale pewnym uzupełnieniem byłoby sięgnięcie do opracowań syntetycznych obszerniej omawiających wizje ustroju II RP . Choć tej formacji politycznej nie udało się wypracować zwartej i jednoznacznej w treści wizji ustroju państwa, to zarówno „starzy”, jak i „młodzi” (mimo odmiennych założeń filozoficznych i poglądu na bieżącą politykę) akcentowali zna-

${ }^{3}$ Więcej S. Bronsztajn, Ludność żydowska w Polsce w okresie międzywojennym. Studium statystyczne, Wrocław 1963; A.S. Kotowski, Narodowa Demokracja wobec nazizmu i Trzeciej Rzeszy, Torun 2006; B. Halczak, Publicystyka narodowa-demokratyczna wobec problemów narodowościowych i etnicznych II Rzeczypospolitej, Zielona Góra 2000; H. Lisiak, Narodowa Demokracja w Wielkopolsce w latach 1919-1939, Poznań 2006, s. 248-269; J.R. Sielezin, Kwestia narodowa i żydowska w prasie Narodowej Demokracji 1987-1939, [w:] Prasa Narodowej Demokracji 1986-1939, red. A. Dawidowicz, E. Maj, Lublin 2010, s. 335-337.

${ }^{4}$ Na przykład J. Jurkiewicz, Nasze widzenie Białorusinów w XX w. (do 1929 r.), „Dzieje Najnowsze” 1995, nr 2; J. Jaguś, Ludność białoruska województwa nowogródzkiego II Rzeczypospolitej, Toruń 2014; J. Tomaszewski, Białorusini w oczach Polski, „Literatura na Świecie” 1991, nr 8-9.

${ }^{5}$ Na przykład K. Kawalec, Wizje ustroju państwa w polskiej myśli politycznej lat 1918-1939, Wrocław 1995; J. Juchnowski, J.R. Sielezin, The Concept of State in Polish Political Thought in the Period 1918-1939, t. 1, Wrocław 2013. 
czenie wartości chrześcijańskich jako normatywnego ładu ustrojowego państwa. Rozdział ten uznaję za wartościowy poznawczo i może być inspirujący dla kolejnej generacji badaczy.

Rozdział szósty wydaje się kluczowy i nader aktualny. Autorka zajęła się problematyką gospodarczą lansowaną przez SN, które dążyło do wypracowania adekwatnego modelu gospodarki i względnie pojętego ładu normatywno-gospodarczego. Plany te i propozycje modernizacyjne przypadły na okres znamienny - światowego kryzysu gospodarczego. Choć państwo polskie miało znaczny potencjał gospodarczy, to w warunkach złożonej sytuacji międzynarodowej napotkało przeszkody uniemożliwiające zbudowanie silnie „niezależnego gospodarstwa narodowego” (s. 385). Spór o wizję gospodarczą Polski, jaki toczył się między „starymi” i „młodymi”, to w istocie (ale nie tylko) konflikt między Romanem Dmowskim a Romanem Rybarskim, który, jak słusznie zauważyła autorka, dotyczył odmiennych wizji rozwiązania problemów gospodarczych Polski. Ta część rozdziału została jednak pobieżnie omówiona. Podrozdziały drugi i trzeci są stosunkowo objętościowo krótkie jak na rozmiary pracy i ciężar problemowy i mają charakter przyczynkarski.

W strukturze pracy także ostatni rozdział jest zbyt krótki, aby można było dogłębnie ocenić koncepcję bezpieczeństwa zewnętrznego Polski, jaką lansowali działacze i publicyści SN. Autorka niewątpliwie słusznie, analizując koncepcję bezpieczeństwa zewnętrznego, oparła ją na dwóch rodzajach polskiego obszaru terytorialnego: 1. terytorium narodowego, 2. terytorium państwowego. Ten wątek został nieco skrótowo potraktowany i nie przeanalizowano tego zagadnienia między innymi w aspekcie deklaracji z 26 stycznia 1934 roku, problemu Wolnego Miasta Gdańska, granicy zachodniej, mniejszości niemieckiej w II RP oraz agresywnej polityki III Rzeszy w latach 1933-1939. Część tych problemów autorka omówiła w ostatnim, krótkim, podrozdziale, przy czym zasadne byłoby połączenie tych podrozdziałów. Wówczas trafniej i pełniej można byłoby zrekapitulować poglądy publicystów SN dotyczące polityki państwa wobec sąsiadów i innych mocarstw europejskich.

Zakończenie, choć krótkie w stosunku do całej struktury pracy, ma jednak walor syntetyczny. Autorce udało się ukazać w rozwoju myśli politycznej SN zmianę pokoleniową. Starsze pokolenie powoli, ale systematycznie było „wypierane” przez młodych doktrynerów i publicystów, którzy w przeciwieństwie do poprzedników inaczej interpretowali na przykład „duchowość bytów takich jak naród”, jak to umownie określiła autorka (s. 351). Zakończenie pracy, które jest przemyślane i klarowne, wskazuje też na umiejętność komprymowania najważniejszych treści poruszonych w pracy i dbałość o określoną koncepcję przekazu.

Ogólnie otrzymaliśmy wartościową pracę, opartą na różnorodnych źródłach i opracowaniach: archiwalnych, bibliograficznych, pamiętnikach, wspomnieniach, relacjach, prasie, opracowaniach słownikowych i encyklopedycznych (s. 363-397). Liczba wykorzystanych w pracy różnorodnych źródeł budzi uznanie i wskazuje na dociekliwość badawczą.

Do drobnych mankamentów dostrzeżonych w pracy należy zaliczyć niekiedy mało precyzyjne definiowanie nazw-kategorii oraz pojęć pełniących funkcję określnika przedmiotu badań. Wówczas autorka nie twierdziłaby, że Narodowa Demokracja to „Zwrot” (s. 13 i 16). Ocena całej pracy wypada bardzo korzystnie i świadczy o twórczym podejściu do przedmiotu badań. Praca niewątpliwie jest znaczącym wkładem w rozwój polskiej myśli politycznej i świadczy o twórczym odwołaniu się do zasady jedności wiedzy i wykorzystanych w recenzowanej książce metod badawczych. Moje zaś nieliczne uwagi krytyczne lub niekiedy polemiczne nie mają zasadniczego wpływu na wysoką jej ocenę. Rozprawę oceniam jako oryginalną i wartościową i polecam nie tylko badaczom myśli politycznej. 